\title{
Technology Acceptance Model (TAM) for Analysis of Online Banking use in PT Bank Rakyat Indonesia, Tbk. Gianyar Branch
}

\author{
I Gede Nyoman Carlos Wiswanatha Mada ${ }^{*}$, Putu Yudha Asteria Putri \\ Faculty of Economic and Business, Universitas Warmadewa, Denpasar, Bali-Indonesia \\ \{carlosmada1688@gmail.com¹,ydhasteria.putri@gmail.com²
}

\begin{abstract}
The aim of this study thoroughly explains the use of online banking which is influenced by the Technology Acceptance Model for customers at PT Bank Takyat Indonesia, Tbk. Gianyar Branch. The study also aims to provide consideration for the management of a bank regarding the importance of focusing attention on the use of online banking in order to improve the quality of service to customers considering that customers are assets for banking financial institutions. This study used 100 samples, namely customers of PT Bank Rakyat Indonesia, Tbk, Gianyar Branch. Determination of the sample using the Slovin formula and data collection techniques carried out by distributing questionnaires with a survey method. To answer the research hypothesis using an analytical tool, namely the multiple linear regression analysis method. From the research results it was found that the Technology Acceptance Model has a positive effect on the use of online banking
\end{abstract}

Keywords: Perceptions of Usefulness; Perceptions of Ease of Use; Computer Self Efficacy; Use of Online Banking

\section{Introduction}

Banking institutions in developing their services are not only based on the use of safe and reliable slogans to attract customers. Banks as banking institutions in Indonesia should be able to provide services in accordance with customers' lifestyles seen from current technological developments. The form of service that is developing in the banking world is online banking services[1]. Online banking. This can be done by customers for banking transaction services anytime and anywhere, from homes, places of business, schools, supermarkets, and in other places other than a bank branch using communication media such as computers or cell phones. The form of bank services that we often encounter and use is the Automatic Teller Machine (ATM) [2]. ATMs currently provide various services to facilitate services to customers such as cash deposits and withdrawals, savings book printing, and cash withdrawals can be made by ATM machines even when employees do not carry an ATM card.

For PT. Bank Rakyat Indonesia (BRI), Tbk. as a state-owned banking company, customer service should be the focus of attention. One of the branches of PT Bank Rakyat Indonesia, Tbk. which has a good performance is the Gianyar Branch of Bank Rakyat Indonesia, which is the only economic driver for MSMEs in the Bali - NTB area. BRI Gianyar Branch has 8 unit offices that are spread throughout the Gianyar Regency. With as many as 88,926 customers, 
both loans and deposits. However, it is very unfortunate that in fact at PT Bank Rakyat Indonesia, especially in the Gianyar branch, there are still things that make customers feel unsatisfied in using online banking services so that customers are not sure to use the online banking services that have been provided, online banking services often have errors so that causing customers to be unable to transact easily. Especially at this time countries in the world, especially Indonesia are being hit by the Covid 19 pandemic, which requires customers to minimize transactions in banks, so focus on the concept of Computer Self Efficacy which makes customers believe to use a computerized system must be planted in each customer to break the chain the spread of the Covid 19 outbreak. It can also be seen that the efforts of banking institutions for social distancing are being carried out, only 15 people can be in the office room of the bank unit, and if you want to quickly make transactions, it is recommended to use the machine that has been provided. Several investigative studies of online banking services on the basis of customer acceptance of technology use have been carried out through expanding the Technology Acceptance Model (TAM) theory. TAM, which was first introduced by [3], argues that customer perceptions of perceived usefulness and perceived ease of use are the main factors affecting the use or adoption of technology. In addition to customer perceptions of perceived usefulness and perceived ease of use, Agarwal et al. in [4] views the concept of Computer Self Efficacy as an important variable for the study of individual behavior in the field of information technology. From the background that has been described, the formulation of the problem is as follows:

- Does the perceived usefulness affect the use of online banking at PT Bank Rakyat Indonesia. Tbk Gianyar Branch?

- Does the perception of convenience affect the use of online banking at PT Bank Rakyat Indonesia. Tbk Gianyar Branch?

- Does computer self-efficacy affect the use of online banking at PT Bank Rakyat Indonesia. Tbk Gianyar Branch?

\section{Literature Review}

\section{Definition of Online Banking}

[5] defines online banking as an internet portal that allows customers to use various banking services from bill payments to investing. Other than that, [6] defines online banking as a number of banking activities that allow customers of the bank concerned to be able to access available information regarding balance reports, transfers, bill payments and others via telecommunication networks without leaving their homes or offices. Based on some of the definitions regarding online banking above, it can be concluded that online banking is a banking activity that can be carried out by customers either from home, business or in other locations that are not in real bank locations (branch offices) using communication media such as computers, cell phones and landlines.

\section{Technology Acceptance Model}

TAM is adapted from Theory of Reasoned Action introduced by [7] and proposed by [3] TAM assumes that a person's acceptance of information technology is influenced by two main variables, namely Perceived Usefulness and Perceived Ease of Use (Perceptions of Ease of Use). The following is a drawing of the initial TAM construct introduced by [3] : 


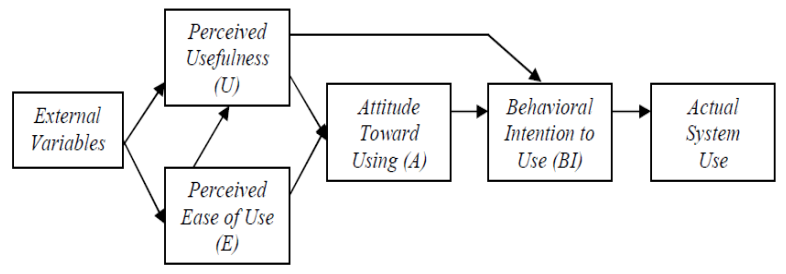

Figure. 1. Technology Acceptance Model (TAM) [3]

Perceived Usefulness (Perceptions of Usefulness) and Perceived Ease of Use (Perceptions of Ease of Use) affect individual Attitude Toward Using towards technology use [2]. The increase in Perceived Ease of Use instrumental in influencing the increase of Perceived Usefulness because a system that is easy to use does not take long to learn so that individuals have the opportunity to do something else that is related to performance effectiveness [3]

\section{Results and Discussion}

After all the classical assumption tests are fulfilled, the next step is to carry out multiple linear regression tests with the basic model as follows:

$$
\begin{array}{ll}
\mathrm{Y}=\alpha+\beta 1 \mathrm{X} 1 & +\beta 2 \mathrm{X} 2+\beta 2 \mathrm{X} 2+\beta 3 \mathrm{X} 3+\varepsilon \ldots \ldots \ldots \ldots . .(1) \\
\text { Information: } & \\
\mathrm{Y} & =\text { Use of online banking } \\
\alpha & =\text { Constant } \\
\beta 1-\beta 3 & =\text { Regression Coefficient } \\
\mathrm{X} 1 & =\text { Ease of Perception } \\
\mathrm{X} 2 & =\text { Perception of Usefulness } \\
\mathrm{X} 3 & =\text { Computer Self Efficacy } \\
\varepsilon & =\text { Other factors that affect the dependent variable (Y) }
\end{array}
$$

The results of multiple linear regression tests can be seen in Table 1. The test was carried out on the perceived ease of use, perceived usefulness, computer self-efficacy in using online banking.

Table 1. Multiple Linear Regression Test Results

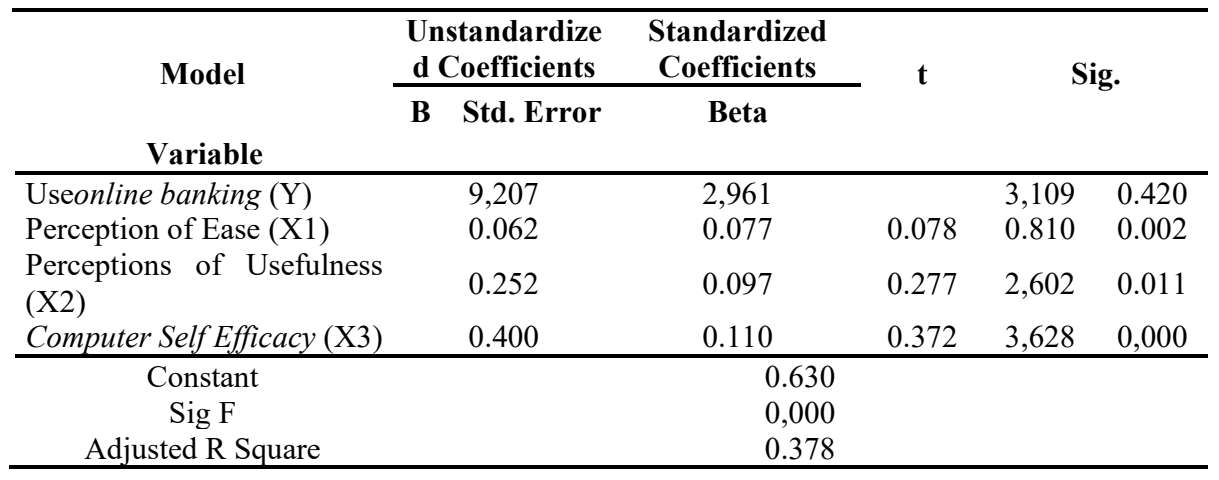


Based on the results of multiple linear regression analysis shown in Table 1, a regression equation can be made as follows:

$$
\mathrm{Y}=\mathbf{0 . 6 3 0}+\mathbf{0 . 0 7 8 \times 1}+\mathbf{0 . 2 7 7} \mathrm{X} 2+\mathbf{0 . 3 7 2 X 3}+\varepsilon
$$

The regression equation coefficient above indicates that the variableperceived ease, perceived usefulness andcomputer self efficacy has a unidirectional influence with the dependent variable, namely the use of online banking. In addition, the regression results also show an Adjusted R Square of 0.378. This shows that the variability of online banking usage variables can be explained by variablesperceived ease, perceived usefulness andcomputer self efficacy $37.8 \%$ percent, while the remaining 62.2 percent is explained by other variables outside the research model. The regression coefficient value of the perceived ease of use variable (X1) is 0.078 , the perceived usefulness (X2) is 0.277 , and computer selfefficacy (X3) is 0.372. at PT Bank Rakyat Indonesia, Gianyar branch.

\section{F Test Statistics}

The results of the $\mathrm{F}$ test or model feasibility test in Table 1 show the effect of all independent variables on the dependent variable. This test is done before testing the hypothesis. If the $\mathrm{F}$ test shows significant results, then all independent variables affect the dependent variable and the model used is feasible, so that hypothesis testing can be continued.

The level of probability (sig.) $\mathrm{F}$ is $0.000 \leq \alpha=0.05$; $\mathrm{H} 1$ is accepted and $\mathrm{H} 0$ is rejected.The results of the study show that the F significance value is 0.000 , which is smaller than $\alpha=0.05$, so it can be concluded that the variables of perceived ease, perceived usefulness and computer self-efficacy simultaneously predict and explain the use of online banking at PT Bank Rakyat Indonesia, Gianyar branch.

\section{Statistical Test $\mathbf{t}$}

The $t$ test results in Table 1 show the effect of the variables perceived ease, perceived usefulness and computer self efficacy on use of online bankingat PT Bank Rakyat Indonesia, the Gianyar branch partially. The test of each independent variable on the dependent variable is described as follows.

\section{InfluencePerceptions of Benefits in Using Online Banking at PT Bank Rakyat Indonesia. Tbk Gianyar Branch}

The first hypothesis (H1) states that the perceived usefulness has a positive effect on the use of online banking at PT Bank Rakyat Indonesia, Tbk. Gianyar Branch.Testing of the effect of perceived usefulness on the use of online banking is carried out by looking at the results of the $t$ statistical test. The level of probability (sig.) $\mathrm{T}$ of the experience variable is $0.011<\alpha=0.05$. This shows that $\mathrm{H} 2$ is accepted and $\mathrm{H} 0$ is rejected. Perceptions of usefulness in online banking are a customer's subjective view of the benefits obtained by customers in improving customer performance due to using online banking. As research conducted by [1] and [8], when the customer has used the online banking service many times, the customer has benefited from the online banking service. Most of the customers at PT Bank Rakyat Indonesia, Tbk. The Gianyar branch believes in the benefits of using online banking in daily activities. So if the higher the perception of the usefulness of online banking for customers, the higher the level of online banking usage for customers at PT Bank Rakyat Indonesia, Tbk. Gianyar Branch.

The Effect of Perceived Ease of Use of Online Banking at PT Bank Rakyat Indonesia. Tbk, Gianyar Branch 
The second hypothesis (H2) states that perceived convenience has a positive effect on the use of online banking at PT Bank Rakyat Indonesia, Tbk. Gianyar Branch.Testing the effect of perceived ease of use on online banking was carried out by looking at the results of the $t$ statistical test. The level of probability (sig.) $\mathrm{T}$ of the experience variable is $0.002<\alpha=$ 0.05. This shows that $\mathrm{H} 1$ is accepted and $\mathrm{H} 0$ is rejected. Perceived Ease of Use of online banking means that customers believe that transacting through online banking is easy to understand. Perceived Ease of Use will reduce the effort (both time and effort) of customers in learning the ins and outs of transacting through online banking. Research conducted by [2] and [9] stated that, if the online banking service was perceived as easy to use by customers, the service would be used frequently. So the higher the perception of convenience, the use of online banking at PT Bank Rakyat Indonesia, Tbk. will also increase. Based on this description, the research hypothesis is formulated:

The influence of computer self-efficacy affects the use of online banking at PT Bank Rakyat Indonesia. Tbk, Gianyar Branch

The third hypothesis (H3) states that computer self-efficacy has a positive effect on the use of online banking at PT Bank Rakyat Indonesia, Tbk. Gianyar Branch.Testing the influence of computer self-efficacy on the use of online banking is done by looking at the results of the $t$ statistical test. The level of probability (sig.) $\mathrm{T}$ of the experience variable is $0.000<\alpha=0.05$. This shows that $\mathrm{H}$

In this study, Computer Self Efficacy refers to an individual assessment of a customer's computing ability in completing transactions through online banking services with a lack of support and assistance from other people, manual transaction manuals and online banking assistance menus. The high level of customer Computer Self Efficacy will further increase the level. the use of online banking itself is in accordance with the research conducted by [6] and $[5]$.

\section{Conclusions}

The purpose of this study is to investigate the extent to which the Theory Acceptance Model (TAM) is implemented, namely the perception of ease and perceived usefulness as well as computer self-efficacy in the use of online banking at PT Bank Rakyat Indonesia, Tbk. Gianyar Branch. This study uses 100 customers who use online banking as the research sample. From the research objectives, it can be concluded that the use of Theory Acceptance Model (TAM) which consists of perceived ease and perceived usefulness as well as computer self-efficacy at PT Bank Rakyat Indonesia, Tbk. The Gianyar branch has a positive effect on the use of online banking. The development of Information Technology is currently very fast, both in terms of the development of Information Technology in terms of hardware and software. On the one hand, this development is very helpful for the novice accountant (the user), while on the other hand there are some users who feel anxious, afraid (affried) and unable to follow these developments or even reject these developments. Customers at PT Bank Rakyat Indonesia, Tbk. The Gianyar branch considers that the easier it is for an Accounting Information System to be implemented when completing work, the higher the confidence of employees to use computers. Customers at PT Bank Rakyat Indonesia, Tbk. The Gianyar branch considers the use of online banking to be very helpful in completing its work. With online banking, customers can be faster in their daily lives and can make information 
more effective and efficient. Behavioral aspects and the ability to apply Management Information Systems are determining factors for the complexity of the Management Information System. The more constructive the behavior and the higher the expertise of the Management Information System users will cause the complexity of the Management Information System to have a positive impact on the company's strategy and business continuity.

This study has several weaknesses that may influence the interpretation of the results. First, many respondents complained that the term Theory Acceptance Model used was too technical. However, several steps have been taken to overcome this. Among other things, sampling is done by explaining to respondents and providing a glossary / meaning of terms along with examples. The second weakness is that the number of samples used is not large and wide so that the research sample experiences similar environmental conditions so that the data collected is not sufficient to produce a statistically significant relationship. Third, the research sample is a customer of PT Bank Rakyat Indonesia, Tbk at the Gianyar branch, so the interpretation of the results for customers at branch offices or other companies must be carried out with caution. Based on the weaknesses that have been described, suggestions for further research are to consider the level of understanding and knowledge of respondents about the importance of understanding and using Management Information Systems. Apart from the three contingent factors that have been used in this study, there are still many factors that can influence the use of online banking. Future studies can use even more factors in order to obtain a more precise research model. Apart from the three contingent factors that have been used in this study, there are still many factors that can influence the use of online banking. Future studies can use even more factors in order to obtain a more precise research model. Apart from the three contingency factors that have been used in this study, there are still many factors that can influence the use of online banking. Future studies can use even more factors in order to obtain a more precise research model.

\section{References}

[1] D. Kurniawan, S. Hatane, and J. Edwin, “Analisis Penerimaan Nasabah terhadap Layanan Mobile Banking dengan Menggunakan Pendekatan Technology Acceptance Model dan Theory of Reasoned Action," J. Manaj. Pemasar., vol. 1, no 1. 2013, pp. $1-13,2013$.

[2] H. Medyawati, C. Marieta, and M. Yunanto, "E-Banking Adoption Analysis Using Technology Acceptance Model (TAM): Empirical Study of Bank Customers in Bekasi City," Int. Conf. Innov. Manag. Serv., vol. 14, pp. 91-95, 2011.

[3] F. D. Davis, "Perceived Usefulness, Perceived Ease of Use, and User Acceptance of Information Technology," MIS Quartely, vol. 13, pp. 319-339, 1989.

[4] Rustiana, "Computer Self Efficacy (CSE) Mahasiswa Akuntansi Dalam Penggunaan Teknologi Informasi: Tinjauan Perspektif Gender," J. Akunt. dan Keuang., vol. 6, no. 1, pp. 29-39, 2004.

[5] A. S. Antasari, "Pengaruh Penggunaan Internet Banking Terhadap Kepuasan Nasabah,” J. Adm. Bisnis, vol. 1, pp. 5-6, 2013.

[6] B. Hermana, "Pengukuran Kualitas Layanan Internet Banking," J. Ekon. Bisnis, vol. 15 , pp. 7-8, 2010 . 
[7] I. Ajzen and M. Fishbein, Understanding Attitudes and Predicting Social Behavior Englewood Cliffs. New Jersey: Prentice-Hall, 1980.

[8] R. Wijayanti, H. Fitriansyah, and A. Armaini, "Analisis Technology Acceptance Model (TAM) Terhadap Faktor-Faktor yang Memengaruhi Penerimaan Nasabah Terhadap Layanan Internet Banking (Studi Empiris Terhadap Nasabah Bank di Depok," Proceeding PESAT (Psikologi, Ekon. Sastra, Arsit. Sipil) Univ. Gunadarma, vol. 4, pp. 121-127, 2011.

[9] Muntianah, "Pengaruh Minat Perilaku terhadap Actual Use Teknologi Informasi dengan Pendekatan Teory Acceptance Model," Profit, vol. 6, no. 1, 2012. 